\title{
斜杭および斜め土圧を考慮した砂地盤における 杭の受働土圧に関する実験的研究
}

\section{1.はじめに}

横移動する杭面，特に，地盤が塑性化する杭の受働土 圧面には，杭頭に作用する鈶直荷重の影響や変形時の杭 と地盤との挙動の相違等によって, 摩擦力が働くことが 推測される。杭の水平抵抗はこの摩擦力に影響されるこ とが考えられるため, 杭の水平支持力を評価する場合, これを考慮した受働土圧（水平極限地盤反力）が必要で あろう。

これまで，土圧の向きを任意に作用させる実験が困難 であったこともあり, 杭と地盤との間の摩擦角を考慮し た受働土圧に関して，積極的な研究が行れなかったのが 現状であろう。筆者らは，限られた若干の模型実験と推 測のもとに地盤の崩壊形状を仮定し，土圧や杭の傾きを 考慮した受働土圧の理論的解析法 (参考文献 ${ }^{1)}$ ) の提案 を行ったが,これも実験的な根拠がそしく, 修正が必要 であると思われる。

本研究は，斜め土圧を考慮した鉛直杭および斜杭の受 働土圧に関する実験法を考案し，これにより砂地盤にお ける種々の受働土圧実験を実施し，それらの諸性状を把 握するとともに, 杭の受働土圧の理論的解析法 (1984) の修正に必要な基礎資料を得ることを目的とするもので ある。

なお，実際には杭の破壊等によって，地盤の塑性化が 比較的浅い領域にとどまることが予想されるため, 本実 験は, 杭径の 9 倍以下の短い根入れ長さ杭を対象とした。

【記号表】

本論文に使用する主な記号は以下のとおりである。

$B:$ 杭径または杭の見付け副

$H_{0}:$ 杭の根入れ長さ

$P, P_{N}:$ 土圧の合力, 土圧の合力の垂直成分

* 日本大学 教授 $\cdot$ 工博

** 東京電力株式会社 $\cdot$ 工修

*** 日本大学 大学院生 $\cdot$ 工修

**** 日本大学 教授 $\cdot$ 工博 (1988 年 11 月 4 日原稿受理, 1989 年 9 月 5 日採用決定)
正会員 国府田

正会貝山下

正会員 佐 藤

利

正会員 榎 並

秀

誠*

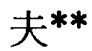

人***

昭****

$N_{P}, Q_{P}$ ：受働土圧の垂直成分，せん断成分（本研究 では最大土圧時を受働状態とし， $N_{P}$ は $P_{N}$ の最大値に等しい)

$H_{P}:$ 杭の根入れ点と土圧合力位置間の距離

$\gamma:$ 土の単位重量

$\eta:$ 土圧の傾き

$\theta:$ 杭の傾き

$\delta_{0}:$ 杭軸に直角な方向の杭の根入れ点の変位

\section{2. 実験概要}

以下に示すような, 杭の根入れ長さ, 杭の傾き, 土圧 の傾き，杭の断面形状および杭の断面寸法を種々変化さ せた砂地盤に対する受㗢土圧実験を行い，それらの諸性 状を調べる。また，受動崩壊地盤の内部観察を行い，地 盤の崩壊性状についても調べる。なお，詳しい実験の内 容は, 各説明の中で述べる。

実験 I：水平および斜め土圧を作用させた鉛直円形杭 の受働土圧実験

実験 II：水平土圧を作用させた円形の鉛直杭および斜 杭の受働土圧実験

実験 IIII：杭に直角な土圧を作用させた円形の鉛直杭お よび斜杭の受働土圧実験

実験 $\mathrm{N}$ ：水平土圧を作用させた鉛直の円形杭， H形杭 , T形杭の受働土圧実験

実験 $\mathrm{V}$ ：水平土圧を作用させた断面寸法の異なる鉛直 円形杭の受働土圧実験

実験 VI：水平および斜め土圧を作用させた鉛直円形杭 の地中受働崩壊形状の観察実験

なお，模型実験によって実大杭の諸性状を定量的に把 握しようとする場合, 相似則あるいは寸法効果等の究明 が大きな課題として，新たな問題点の究明が必要となる が，模型実験は，同一条件下で数多くの実験が可能であ り,さまざまな載荷が可能であるため, 模型杭の範囲内 ではあるが, 諸性状を定量的に把握できる等, 実大実験 にはない多くの優れた点があり, 支持力の発揮機構の解 
明や理論解を導く上で多くの基礎的知識を与えるものと 思われる。

\section{3. 実験方法}

\section{1 模型杭}

模型杭は図一 1 および表一 1 に示すように，円形， $\mathrm{H}$ 形， T形の 3 種類の鋼製杭を使用し，打撃によって模型 地盤に挿入した。ただし，T形杭は平形杭を想定しここ れを補強し T形としたものである。また，杭体表面は黒 皮状態で, 模型地盤との間の摩擦角は $25^{\circ}$ 以上を有し, 本実験範囲では，模型地盤と杭の受㗢土圧面はすべり状 態にならないことを確かめている。

なお，受働土圧面がすべり状態にならない範囲（土圧 の傾きが杭と地盤の摩擦角以下の範囲) では, 杭体は受 働崩壊地盤とともに上方向に移動し, 杭先端地盤に対し て引抜き状態になるため, 杭先端地盤反力は小さく，無 視できるものと思われるが，図一1cに示すように，杭 体の先端背面部が先端地盤をえぐり取り，図示のような 杭先端地盤反力が生ずる心配があるため, 同図 bに示す ように杭の先端背面部を切り落とし, 杭先端に大きな地 盤反力が生じないように配慮した（図一1d）。

\section{2 模型地盤の作成方法}

気乾状態の豊浦標準砂を用い, 図一 2 および写真一 1 に示す装置によって，模型地盤を作成した（表一2）。本 地盤作成装置は径 $5 \mathrm{~mm}$ の落下口を縦横とも $10 \mathrm{~cm}$ 間隔 で一様に配置し, 径 $1.5 \mathrm{~mm}$ の網 1 枚を通して, 砂を分 散落下させる方式である。なお，実験槽は図一 3 に示す ように，平面の大きさ縦 $\times$ 横 $=1.5 \mathrm{~m} \times 2.3 \mathrm{~m}$, 深さは $7.5 \mathrm{~cm} \times 7.5 \mathrm{~cm}$ の角パイプを実験槽の側壁に用い，そ の段数の增减によって調節するものである。

表中の内部摩擦角の值は, 豊浦標準砂に対する土質工 学会全国一斉せん断試験（間隙比と内部摩擦角の関係） 等より求めたものである (参考文献 $\left.{ }^{2}\right) 。$

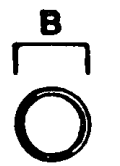

円形机

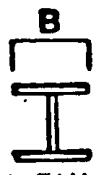

$\mathrm{H}$ 形满 a 断面形<smiles>C=CC=CCCCC</smiles>
丹形埗

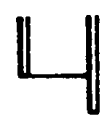

H路妔 b 杭先端

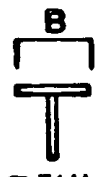

T非机
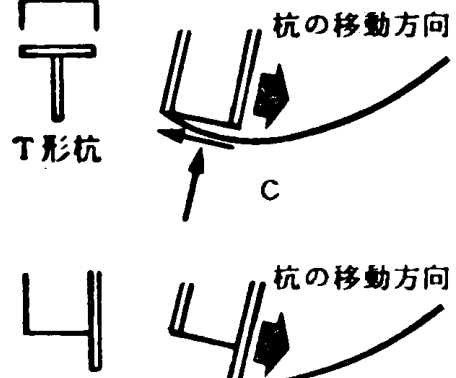

T非机

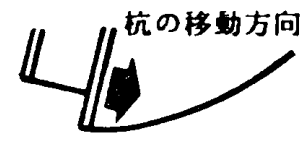

d 図-1＼cjkstart模型杭

\begin{tabular}{|c|c|c|c|c|c|}
\hline \multicolumn{6}{|c|}{ 表一1 } \\
\hline & & 形杭 & & 円形杭 & T形杭 \\
\hline 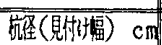 & 7.62 & 4.86 & 3.40 & 7.62 & 7.62 \\
\hline 肉 厚 $\mathrm{cm}$ & 0.30 & 0.30 & 0.30 & 0.60 & 0.60 \\
\hline 重 $\quad$ 量 $\mathrm{kg}$ & 9.65 & 5.21 & 3.92 & 14.81 & 10.49 \\
\hline
\end{tabular}

\begin{tabular}{|lcc|}
\multicolumn{1}{c}{ 表一2 } \\
\hline 使用砂 & \multicolumn{2}{c|}{ 豊浦標準砂 $($ 気乾状態) } \\
土粒子比重 & 2.662 & $\mathrm{~g} / \mathrm{cm}^{3}$ \\
単位重量 & 1.630 & $\mathrm{~g} / \mathrm{cm}^{3}$ \\
間隙比 & 0.633 & \\
含水比 & $0.18 \sim 0.35$ & $\%$ \\
内部摩擦角 & 45 & $\mathrm{deg}$ \\
\hline
\end{tabular}
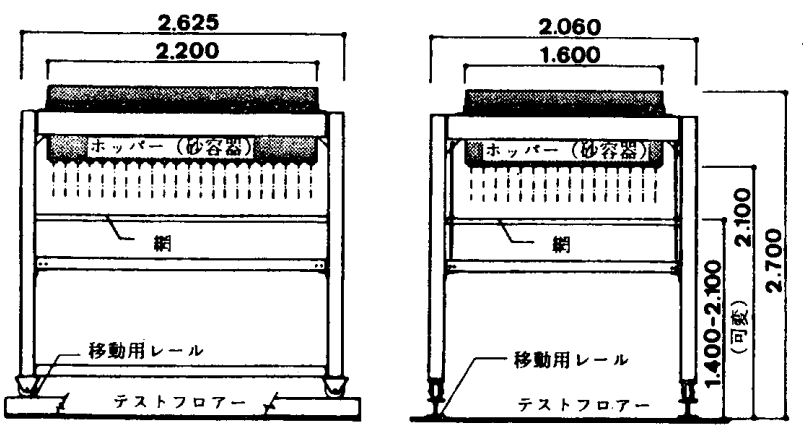

图一2 地盤作成装置

\section{3 載荷および計測方法}

実験は，図一4および図一6に示すように，土圧が所 定の傾き $\eta$ で作用し, 荷重および変位が計測できるよ うに, 以下のように, 計測機器（ロードセルおよび変位 計）を設置する。

(1) 杭重心位置より, 杭の総重量 $W$ に等しい荷重を 滑車を介して差し引く。

(2) 杭頭部の反力 $R$ が所定の土圧の傾き $\eta$ に平行に なるように，ロードセルを介して，杭頭部と支持点をピ ン接合する。ただし，土圧の傾き $\eta$ の符号は図一 5 に示 すとおりである。

(3) 杭の中間点において, 荷重 $F$ が土圧の傾き $\eta$ と 平行に作用するようにロードセルを介して，荷重装置に ピン接合する。

(4) 適当な間隔をおいて 2 個の変位計を設置する。

以上によって, 荷重装置が変位すると杭頂付近を中心 とした杭の回転運動によって, 根入れ部分の杭は横移動 し，移動方向面に傾き $\eta$ の土圧が作用することになる。

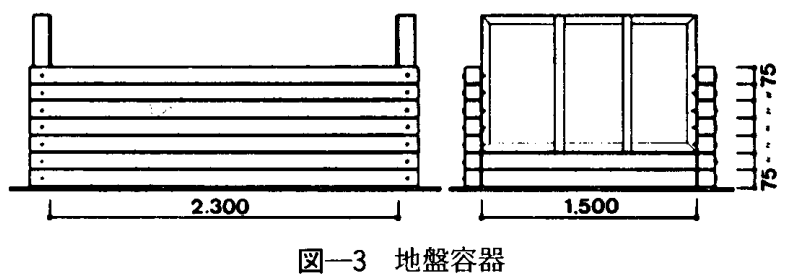

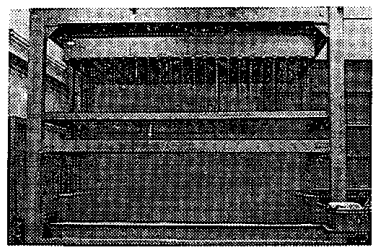

写真一1 地盤作成装置

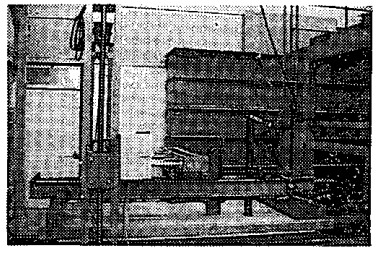

写真一2 実験風景 
この時, 土王の合力 $P$, その作用点距離 $H_{P}$ および杭設 置時の根入点における杭軸に直角な方向の杭変位 $\delta_{0}$ は, 杭頭部および杭中間部に設けられたロードセルの読み值

$(F, R)$ および変位計の読み值 $\left(\delta_{1}, \delta_{2}\right)$ より次のよう に計算される。

$$
\begin{aligned}
& P=F-R \cdots \cdots \ldots \ldots \ldots \ldots \ldots \ldots \ldots \ldots \\
& \delta_{0}=\delta_{1}+\left(\delta_{2}-\delta_{1}\right) \times \frac{E_{G 1}+E_{G 2}}{E_{G 1}} \\
& H_{P}=\frac{\left[R\left(E_{1}+E_{2}\right)-F E_{2}\right]}{F-R} \ldots \ldots
\end{aligned}
$$

また, 最大土圧時（ $P_{\text {max }}$ 時）を受働土圧状態とみな し, 受働土圧の垂直成分の合力 $N_{P}$ およびせん断成分の 合力 $Q_{P}$ を次のように与える。

$$
\begin{aligned}
& N_{P}=P_{\max } \cos \eta \\
& Q_{P}=P_{\max } \sin \eta
\end{aligned}
$$

ただし本実験法は, (1)杭背面の主働土圧は, 受働土生 に比べると非常に小さい值になることが推測されるた め, これを無視した。(2)杭変位が大きくなると, 杭の傾 き, 荷重の向き, 支持反力の向き等の幾何学的関係が損 なわれることになる。本実験では地上部分の杭長さを大 きくすることによって,横移動に伴う回転量を小さくし， この幾何学的誤差を無視した。なお, 本実験において測 定された杭の回転量は, 最大土珪（受働土圧時）にお いて $1.0^{\circ}$ 以下, $5 \mathrm{~cm}$ 変位時において $3.0^{\circ}$ 以下であっ た。

\section{4 崩壊地盤の観察方法}

地表面に表れる受働崩壊形状の観察は，写真およびス ケッチにより行ったが, 地中崩壊形の観察は実際の式験 に対応した形状が観察ができる透水切断方式（仮称）を 用いた。これは, 図一7に示す実験層に, 厚さ $2.5 \mathrm{~cm}$ ごとに着色した砂によって薄い層を設けた模型地盤を作
成し，ほかの試験と同様に載荷する。地盤が崩壊した後， 崩壊形を乱さぬように試験体を固定し, 実験槽ごこ水槽 につけ, 地盤に水を十分に浸透させる。その後, 水槽か ら引き揚げ，十分に排水した後，実験槽の側壁をはずし て地盤をカットする方法である。これは, 水分を含んだ
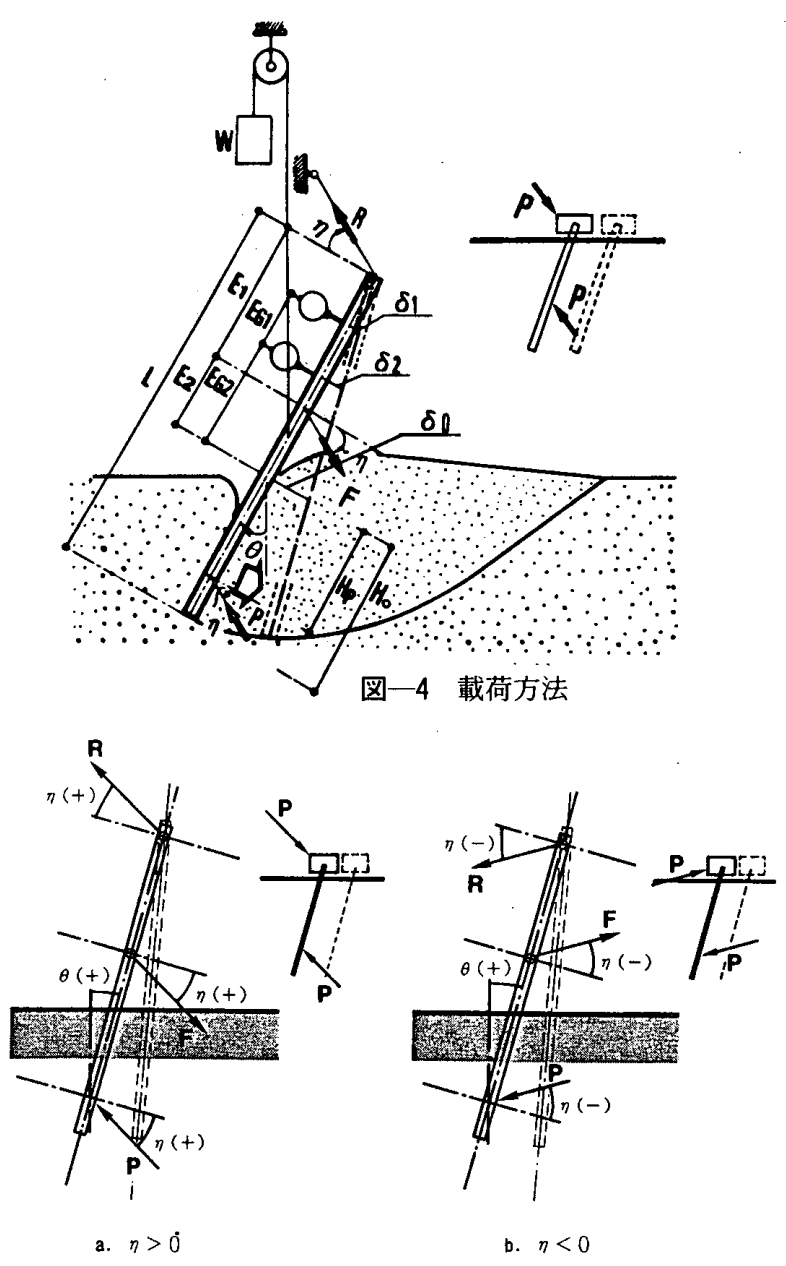

図一 -5 土圧の傾き $\eta$

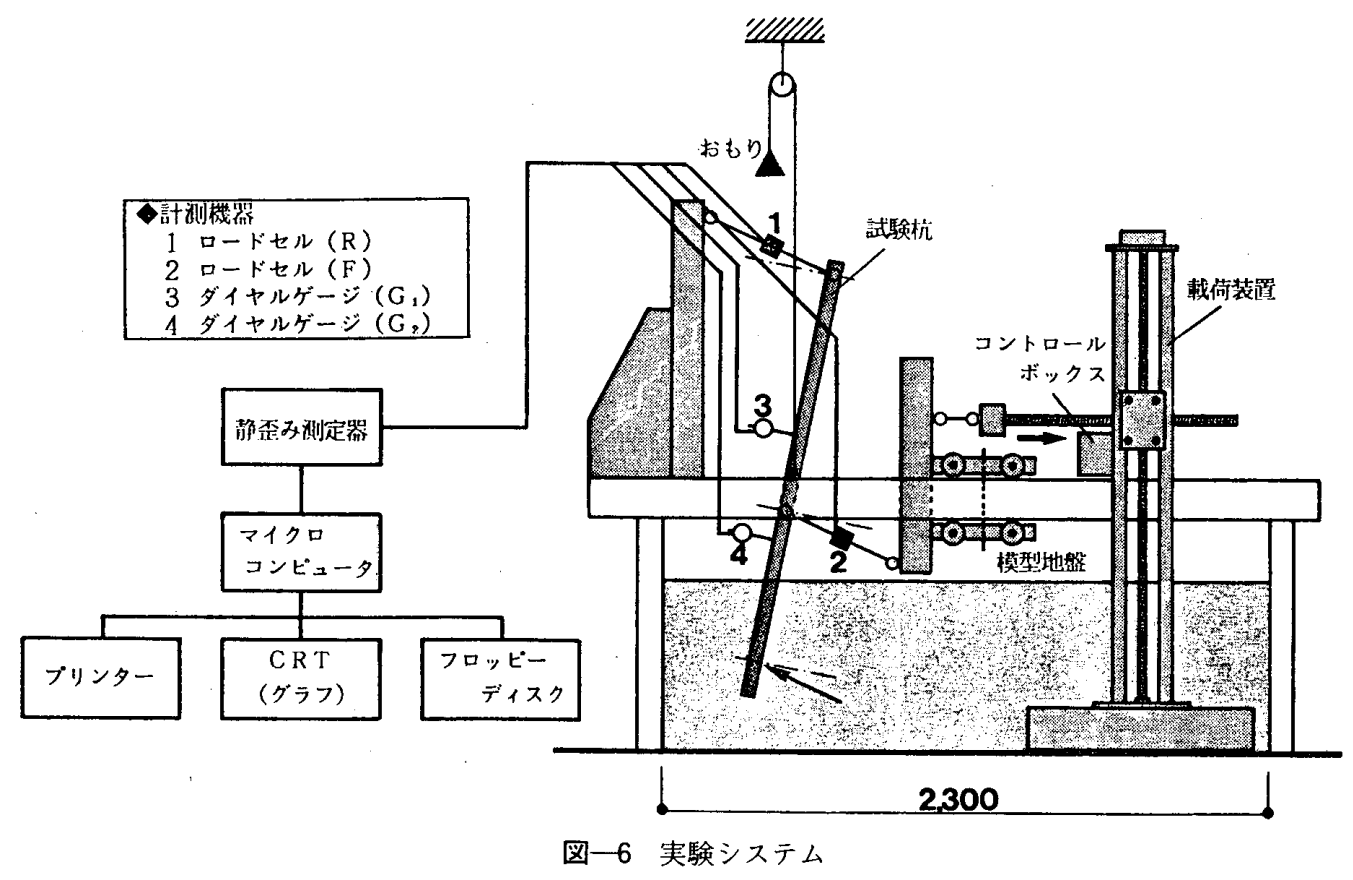




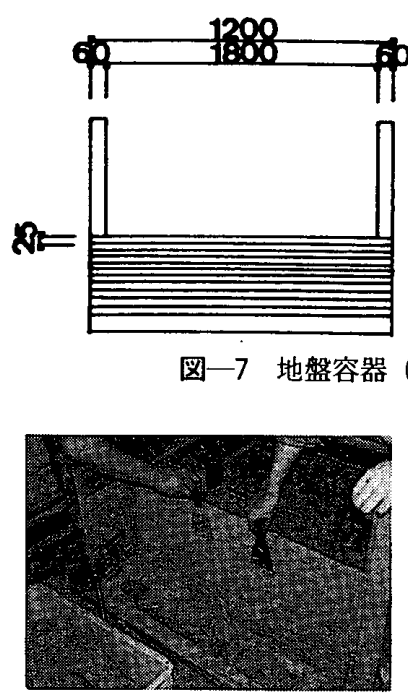

写真一3縦断面カット風景

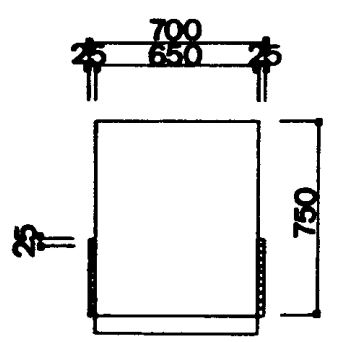

(地中崩壊形観察用)

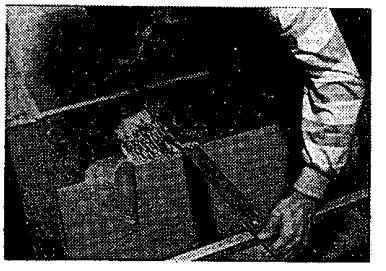

写真一4 水平断面カット風景

砂が水の介在によって生じる粘着力によって自立し，鉛 直にカットすることが可能になること，地盤の破壊領域 （すべり線）は体積の膨張によって間隙比が変化し, 視 覚的に識別できるようになることに着目したものである

(写真一 3,4$)$ 。

\section{4. 実倹結果および考察}

4.1 実験 I (水平および斜め土圧を作用させた鉛直円 形杭の受働土圧実験)

本実験は, 図一8に示すように, 鉛直杭に対して 5 種 類の土圧の傾き $\eta=-20^{\circ},-10^{\circ}, 0^{\circ},+10^{\circ},+20^{\circ}$ に対 する受働土圧実験であり, 土圧の傾きの影響を調べるこ とを主目的としたものである。ただし，実験諸元は表一 3 に示すとおりである。

図一9の各図は, 土圧 $P$ の垂直成分 $P_{N}$ の無次元量 $P_{N} / \gamma B^{3}$ と地表面変位 $\delta_{0}$ の関係 $\left(P_{N} / \gamma B^{3}-\delta_{0}\right.$ 曲線 $)$, 土 圧の合力位置比 $H_{P} / H_{0}$ と地表面変位 $\delta_{0}$ との関係

$\left(H_{P} / H_{0}-\delta_{0}\right.$ 曲線) および地表面の崩壊形状を表したも のである。また図一10 は受働土圧の垂直成分の合力 $N_{P}$ $\left(P_{N}\right.$ の最大值）の無次元量 $N_{P} / \gamma B^{3}$ と土圧の傾き $\eta の$ 関係を示したものである。

これらより以下のことが考察される。

(1) 受働土圧 $N_{P}$ は，土圧の傾き $\eta$ が正の向きに大き くなると増大し，負の向きに大きくなると減少する。土 圧の傾きが $-20^{\circ}$ と $+20^{\circ}$ では約 3 倍の差が生じている

(図一10)。これは受働土圧の大きさが土圧の傾きに依 存することを表しており，壁体土圧と同様，杭において も，地盤との間の摩擦力を考慮する必要があることを意 味している。

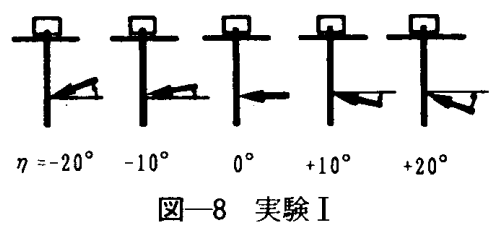

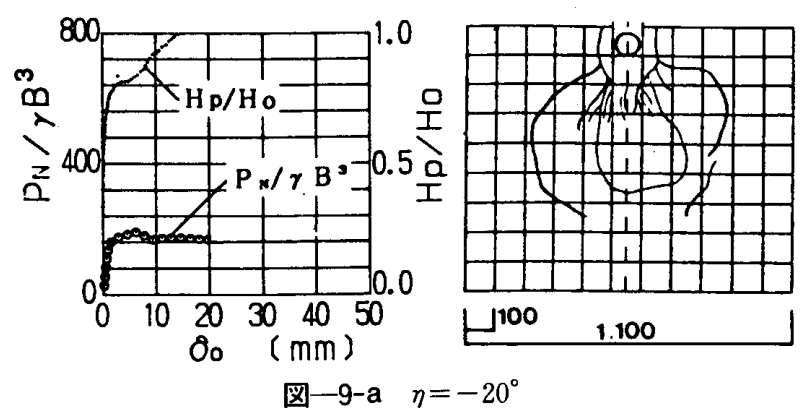
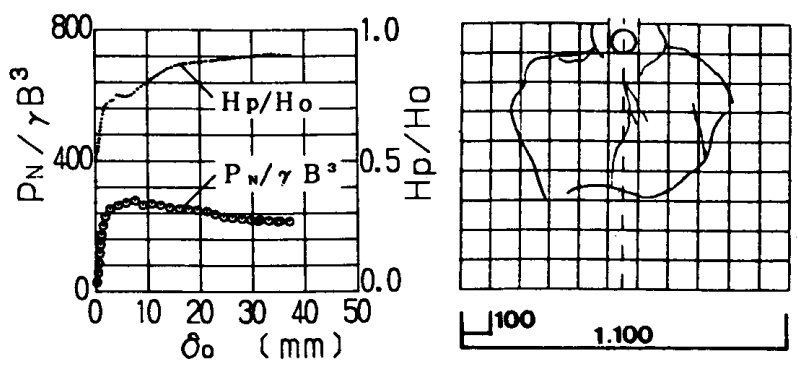

图-9-b $\eta=-10^{\circ}$
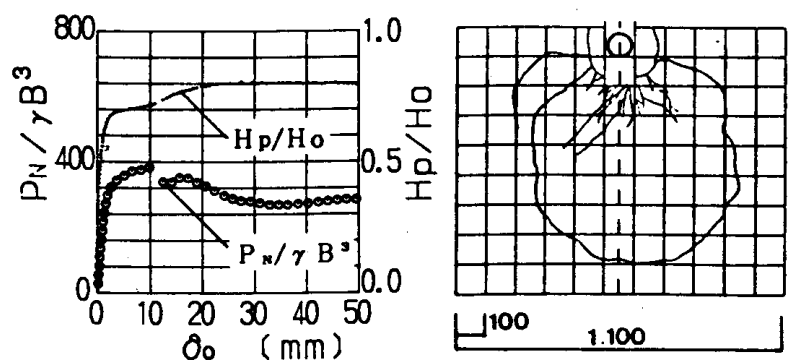

图-9-c $\eta=0^{\circ}$
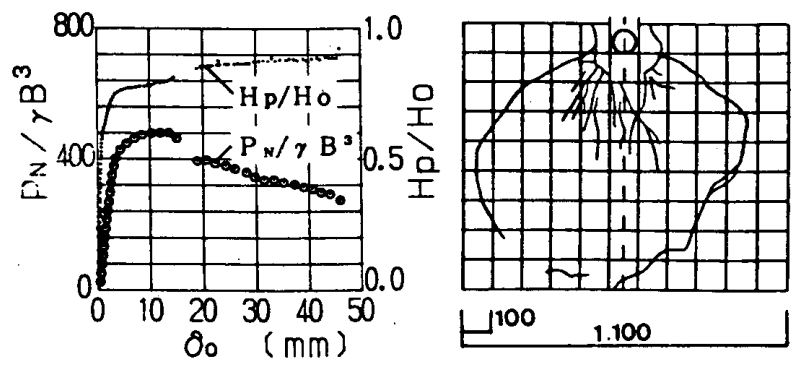

図-9-d $\eta=+10^{\circ}$
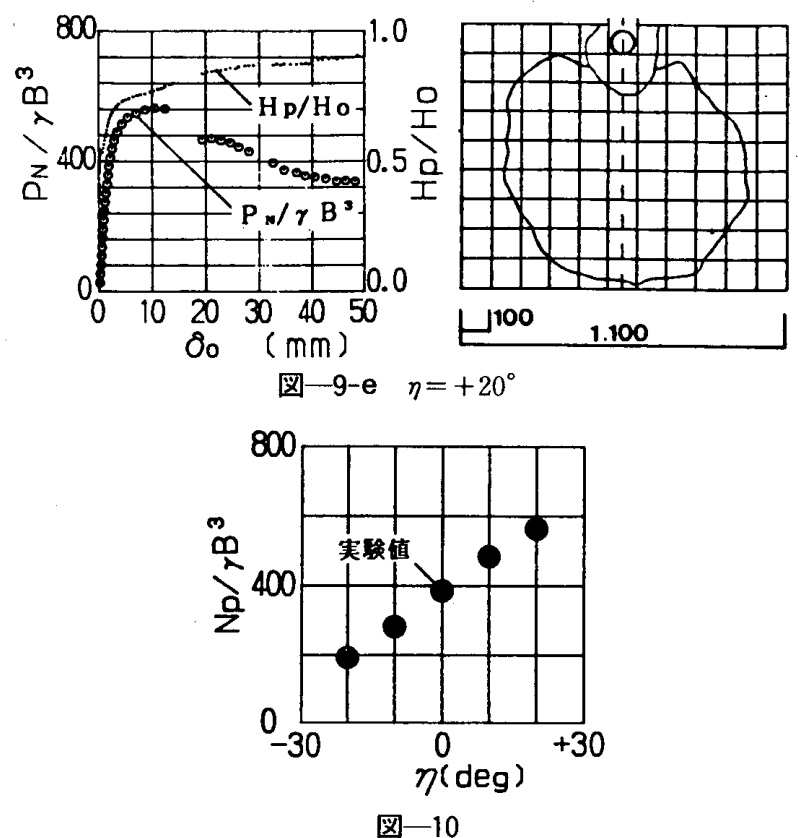

図-10 


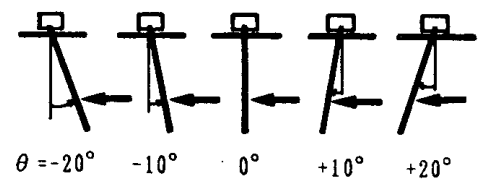

图一11 実験 II
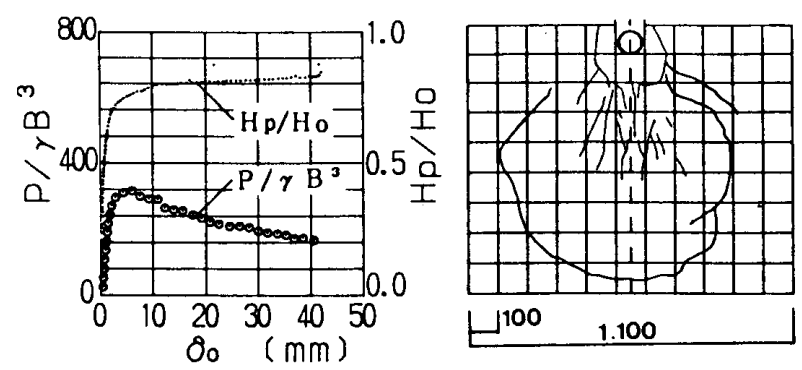

図-12-a $\quad \theta=-20^{\circ}$
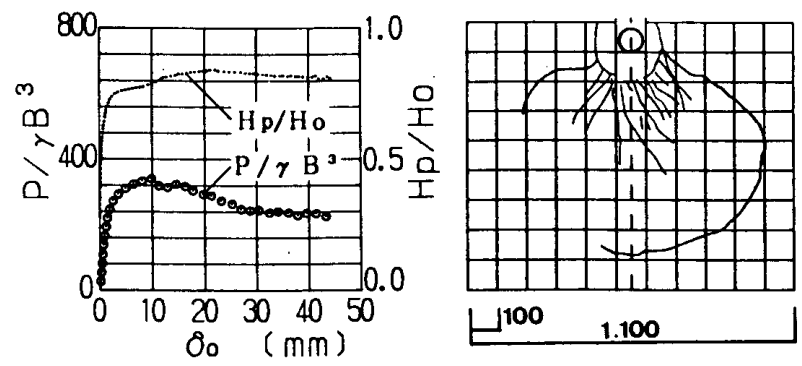

図-12-b $\quad \theta=-10^{\circ}$
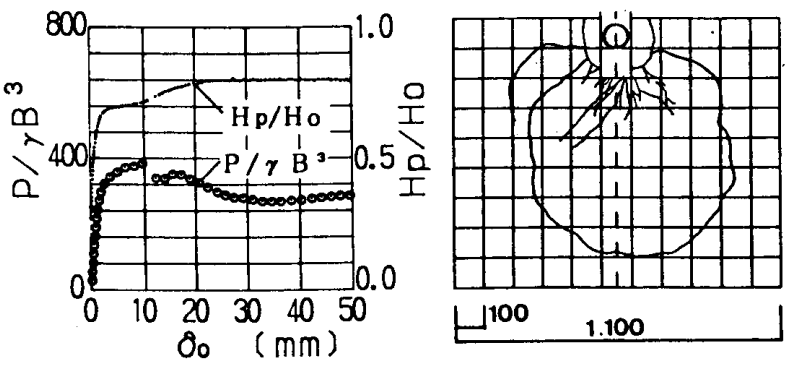

图-12-c $\theta=0^{\circ}$
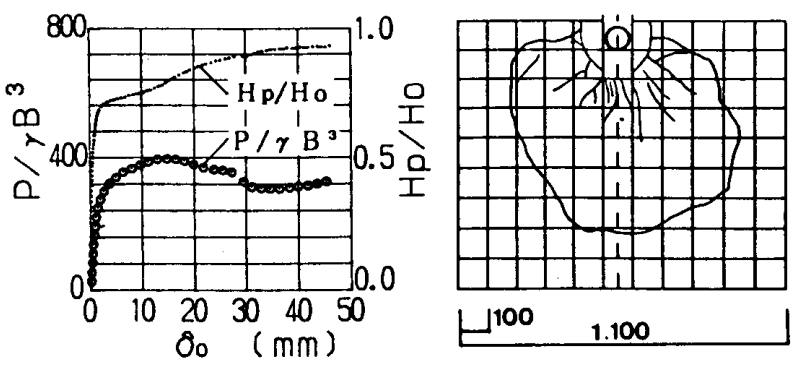

図-12-d $\theta=+10^{\circ}$
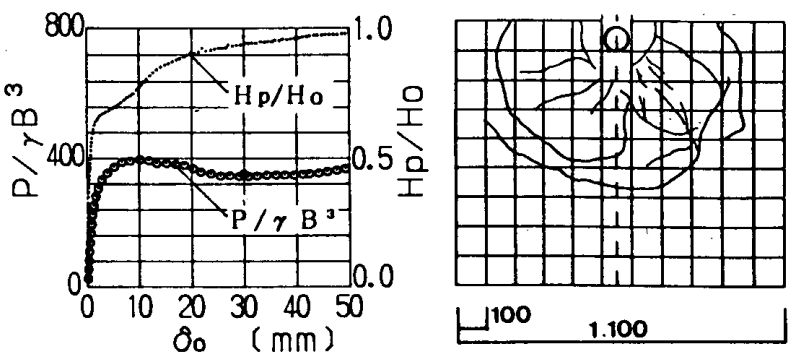

图-12-e $\theta=+20^{\circ}$
表-3

\begin{tabular}{|l|l|}
$\mathrm{L}_{1}=137.2 \mathrm{~cm}$ & $\mathrm{~W}=9.65 \mathrm{~kg}$ \\
$\mathrm{E}_{1}=80.0 \mathrm{~cm}$ & $\mathrm{~B}=7.62 \mathrm{~cm}$ \\
$\mathrm{E}_{2}=19.1 \mathrm{~cm}$ & $\theta=0^{\circ}$ \\
$\mathrm{E}_{\mathrm{G}_{1}}=30.0 \mathrm{~cm}$ & $\eta:$ 図 8 参照 \\
$\mathrm{E}_{\mathrm{G}_{2}}=19.1 \mathrm{~cm}$ & $\mathrm{H}_{0}=38.10 \mathrm{~cm}$ \\
\hline
\end{tabular}

\begin{tabular}{|l|l|}
\multicolumn{2}{|l|}{ 表一 } \\
$\mathrm{L}_{1}=137.2 \mathrm{~cm}$ & $\mathrm{~W}=9.65 \mathrm{~kg}$ \\
$\mathrm{E}_{1}=80.0 \mathrm{~cm}$ & $\mathrm{~B}=7.62 \mathrm{~cm}$ \\
$\mathrm{E}_{2}=19.1 \mathrm{~cm}$ & $\theta \quad:$ 図 11 参照 \\
$\mathrm{E}_{\mathrm{G}_{1}}=30.0 \mathrm{~cm}$ & $\eta=-\theta$ \\
$\mathrm{E}_{\mathrm{G}_{2}}=19.1 \mathrm{~cm}$ & $\mathrm{H}_{\mathrm{O}}=38.10 \mathrm{~cm}$ \\
\hline
\end{tabular}

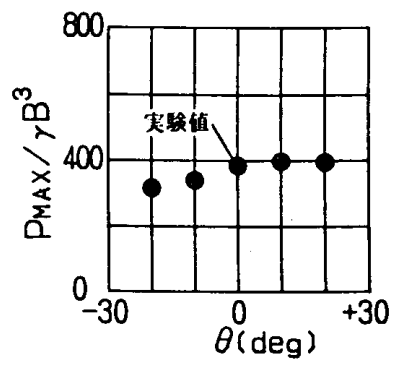

图一13

(2) 受働状態における合力位置比は，0.7〜0.8であ り, 直線土圧分布の合力位置比 $2 / 3$ よりも大きい值を示 している(図一9)。

(3)地表面での地盤の崩壊形状は，ほぼ円形をなし， 土圧の傾きが正の向きに増大すると大きくなり，負の向 きに増大すると小さくなることを示している（図一-9）。 これは, 上記受働土圧と同様，崩壊形状の大きさも土圧 の傾きに依存することを意味している。

4.2 実験 II（水平土圧を作用させた円形の鉛直杭お よび斜杭の受働土王実験)

本実験は図一11に示すように, 杭の傾き $\theta=-20^{\circ}$, $-10^{\circ}, 0^{\circ},+10^{\circ},+20^{\circ}$ に対して水平土压を作用させた 受働土圧実験であり，杭の傾きの影響を調べることを主 目的亡するものである (表一4)。

図一12の各図は $P / \gamma B^{3}-\delta_{0}$ 曲線, $H_{P} / H_{0}-\delta_{0}$ 曲線, および地表面の崩壊形状を表したものであり，図一 13 は土圧合力の最大值 $P_{\max }$ の無次元量 $P_{\max } / \gamma B^{3}$ と杭の 傾き $\theta$ との関係を示したものである。

これらより以下のことが考察される。

(1) 水平土圧時における受働土王は, 杭の傾きが正の 向きに大きくなると増大し，負の向きに大きくなると減 少する傾向にあるが, その差は小さい(図一13)。これは, 水平土圧時における受㗢土圧は，杭の傾きによる影響が 少ないことを意味している。

(2) 受働状態における合力位置比は, 実験 I と同様 0.7 - 0.8 の範囲にあり, いずれも三角形土圧分布の合 力位置比 $2 / 3$ よりも大きいことを示している（図一 $12 ） 。$

（3）地表面に表れる地盤の崩壊形状は, 若干の差が認 

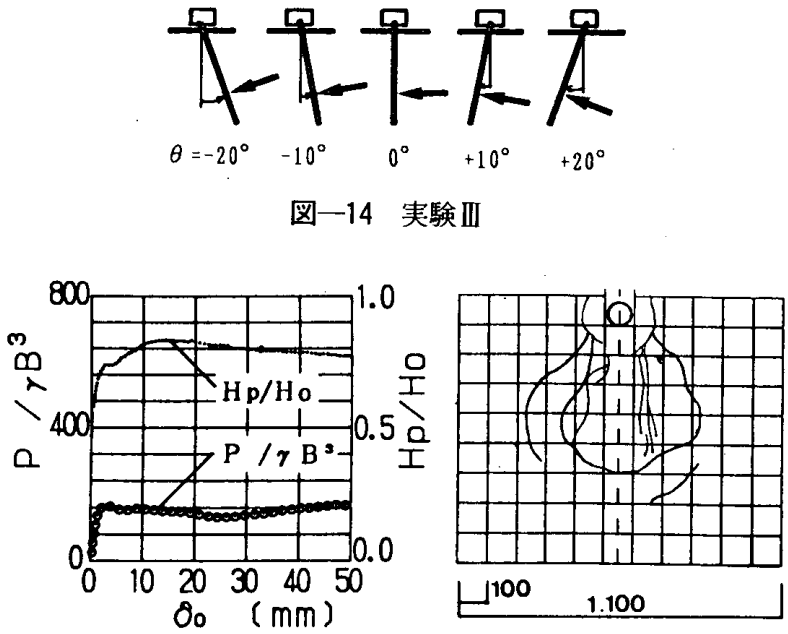

図-15-a $\quad \theta=-20^{\circ}$
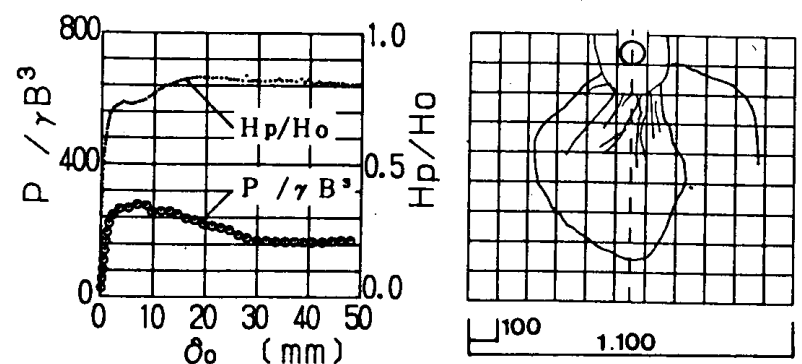

図一15-b $\theta=-10^{\circ}$
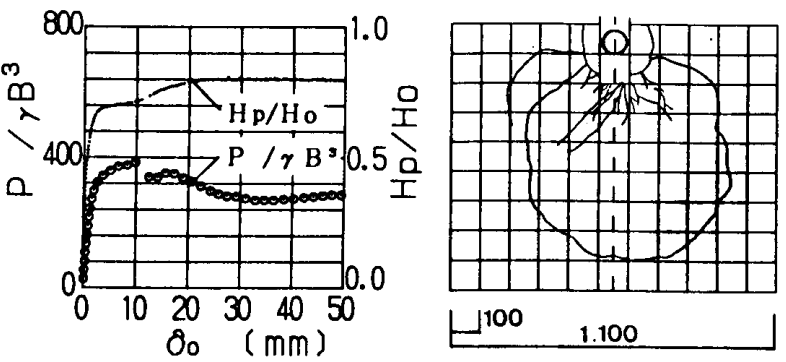

図-15-c $\theta=0^{\circ}$
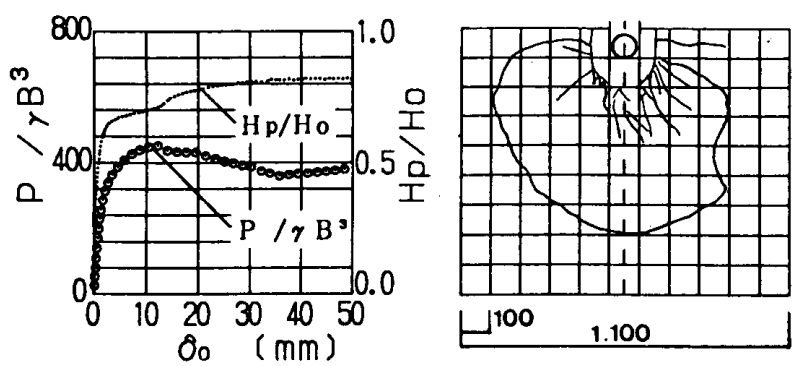

图一15-d $\theta=+10^{\circ}$
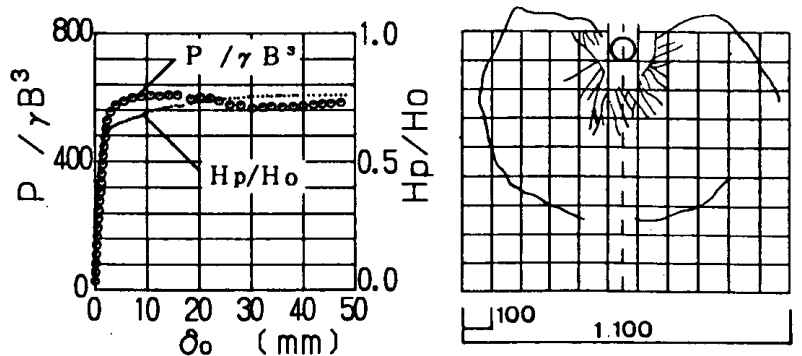

図-15-e $\theta=+20^{\circ}$

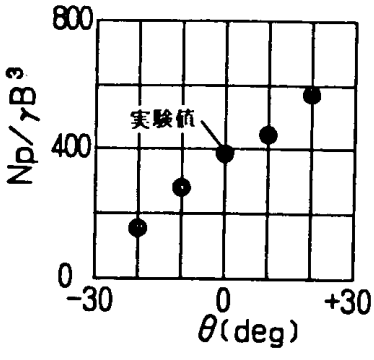

図-16

表-5

\begin{tabular}{|l|l|}
\hline $\mathrm{L}_{1}=137.2 \mathrm{~cm}$ & $\mathrm{~W}=9.65 \mathrm{~kg}$ \\
$\mathrm{E}_{1}=80.0 \mathrm{~cm}$ & $\mathrm{~B}=7.62 \mathrm{~cm}$ \\
$\mathrm{E}_{2}=19.1 \mathrm{~cm}$ & $\theta=$ : 図14参照 \\
$\mathrm{E}_{\mathrm{G}_{1}}=30.0 \mathrm{~cm}$ & $\eta=0^{\circ}$ \\
$\mathrm{E}_{\mathrm{G}_{2}}=19.1 \mathrm{~cm}$ & $\mathrm{H}_{0}=38.10 \mathrm{~cm}$ \\
\hline
\end{tabular}

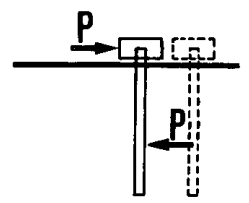

図-17

\begin{tabular}{|l|l|}
\hline \multicolumn{2}{|c|}{ 表 6} \\
$\mathrm{~L}_{1}=137.2 \mathrm{~cm}$ & $\mathrm{~B}=7.62 \mathrm{~cm}$ \\
$\mathrm{E}_{1}=80.0 \mathrm{~cm}$ & $\theta=0^{\circ}$ \\
$\mathrm{E}_{2}=19.1 \mathrm{~cm}$ & $\eta=0^{\circ}$ \\
$\mathrm{E}_{\mathrm{G}_{1}}=30.0 \mathrm{~cm}$ & $\mathrm{H}_{0}=38.10 \mathrm{~cm}$ \\
$\mathrm{E}_{\mathrm{G}_{2}}=19.1 \mathrm{~cm}$ &
\end{tabular}

められるが，ほぼ円形を示している。また，杭の傾きに よる崩壊形状の大きさの差は少ない（図一12）。これは， 上記受働土圧と同様，水平土圧時における崩壊形状は， 杭の傾きによる影響が少ないことを意味している。

4.3 実験 III（杭に直角な土圧を作用させた円形の鉛 直杭および斜杭の受㗢土圧実験）

本実験は, 杭の傾き $\theta=-20^{\circ},-10^{\circ}, 0^{\circ},+10^{\circ},+$ $20^{\circ}$ に対して，杭に直角な向きの土圧を作用させた受働 土圧実験であり，(図一14），杭の傾きおよび土圧の傾き による影響を調べることを主目的としたものである（表 $-5)$ 。

図一15 の各図は, $P / \gamma B^{3}-\delta_{0}$ 曲線, $H_{P} / H_{0}-\delta_{0}$ 曲線, および地表面の崩壊形状を表したものであり, 図一16 は $N_{P} / \gamma B^{3}$ と杭の傾き $\theta$ との関係を示したものである。

これらより以下のことが考察される。

(1) 受働土圧 $N_{P}$ は杭の傾きが正の向きに大きくなる と増大し, 負の向きに大きくなると減少しており, 杭の 傾きが $-20^{\circ}$ と $+20^{\circ}$ とでは約 3 倍の差が認められる (図一16)。

(2) 受働状態における受働土圧の合力位置比は，0.7 ～0.8 の範囲にあり，いずれも三角形土圧分布における 合力位置比 $2 / 3$ よりも大きい值を示している（図一15）。

(3) 地表面の崩壊形状は，いずれもほぼ円形もなして いるが，杭の傾きが正の向きに増大すると大きくなり， 負の向きに増大すると小さくなることを示している（図 $-15)$ 。

4.4 実験 $\mathrm{N}$ (水平土圧を作用させた鉛直の円形杭, $\mathrm{H}$ 形杭， T形杭の受働土圧実験） 
本実験は，杭径または見付け幅を同じくした，三種類 の断面形状を有する模型杭 (円形・H 形・ T 形：図一1 参照）に対する受働土圧実験であり，杭の断面形状の影
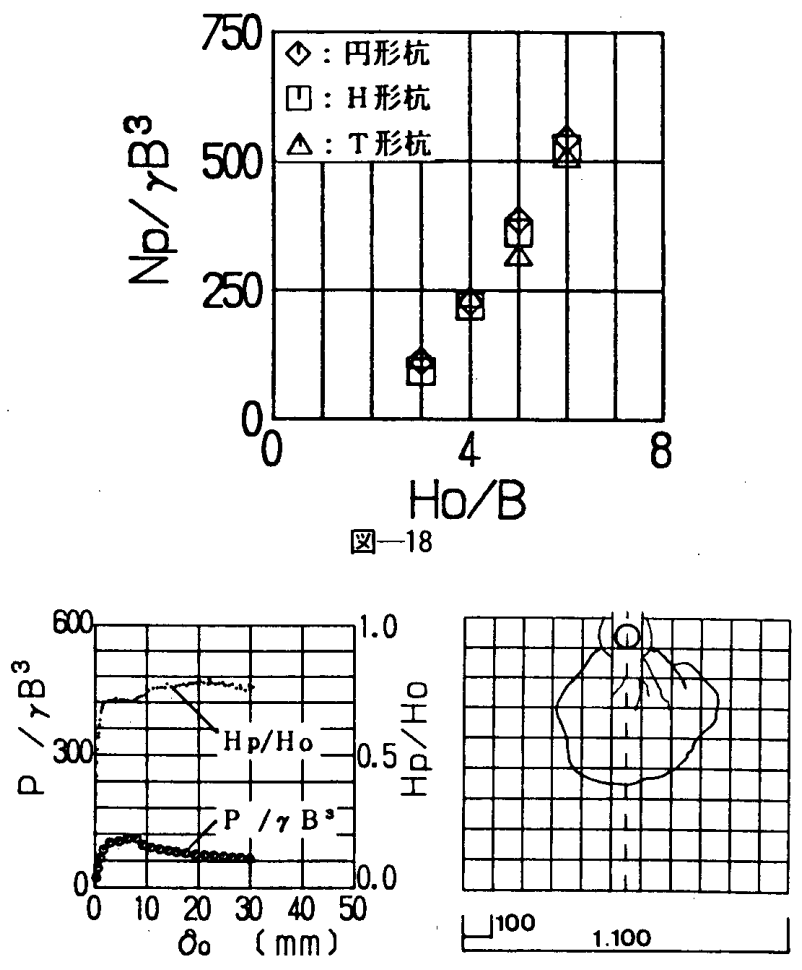

a. 円形杭 $(H=14.56 \mathrm{~cm})$

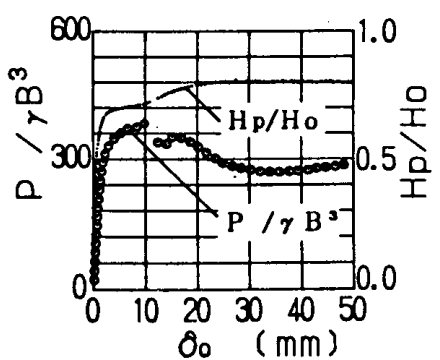

c. 円形杭 $(H=24.30 \mathrm{~cm})$

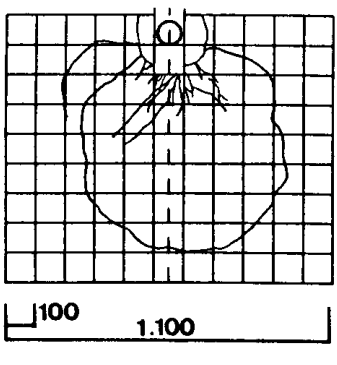

図一19 円形杭
響を調べることを目的として行ったものである(表一6)。 図一19 は円形杭, 図一 20 は $\mathrm{H}$ 形杭, 図一21 は $\mathrm{T}$ 形杭 における $P / \gamma B^{3}-\delta_{0}$ 曲線, $H_{P} / H_{0}-\delta_{0}$ 曲線, および地 表面における地盤の崩壊形状を示したものであり, 各図 の $\mathrm{a} \sim \mathrm{d}$ は順に根入長さの無次元量 $H_{0} / B=3,4,5,6$ に対するものである。図一 18 はこれらの $N_{P} / \gamma B^{3}$ と $H_{0} / B$ の関係を表したものである。

これらより以下のことが考察される。

(1) 受働土圧 $N_{P}$ は, 根入れ梁さが大きい時, 円形, $\mathrm{H}$ 形， T形の順に若干大きくなる傾向が認められるが, 断面形状による顕著な差は認められない（図一18）。

(2) 受働状態時における合力位置比はいずれの根入れ 深さにおいてもほぼ同等であり，断面形状による差は認 められない（図一19－図一21）。

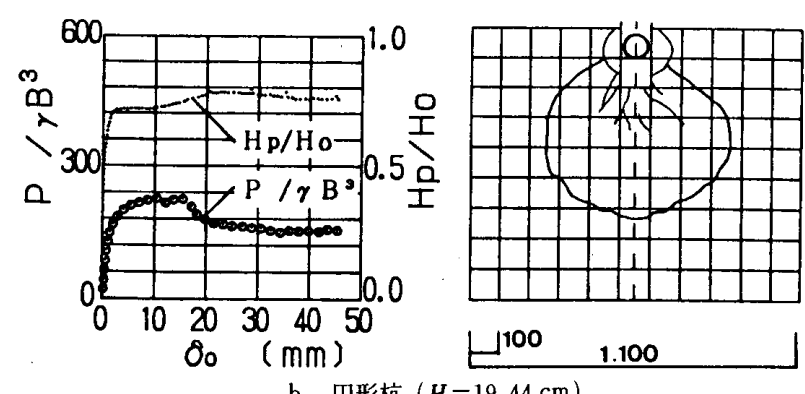

b. 円形杭 $(H=19.44 \mathrm{~cm})$
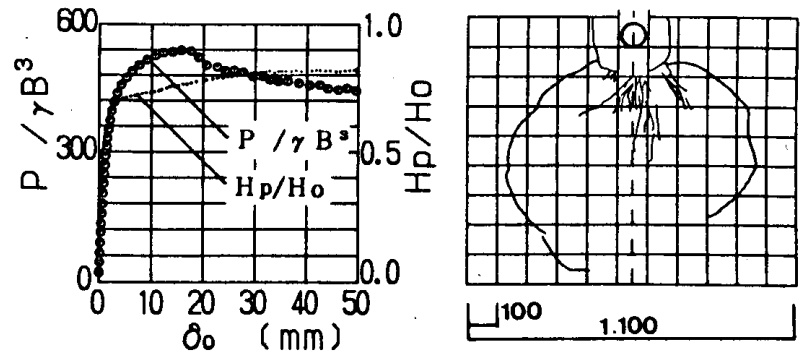

d. 円形杭 $(H=29.16 \mathrm{~cm})$
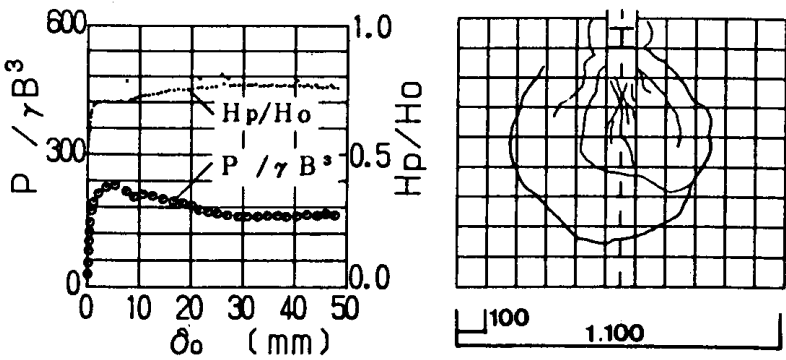

b. H形杭 $(H=19.44 \mathrm{~cm})$
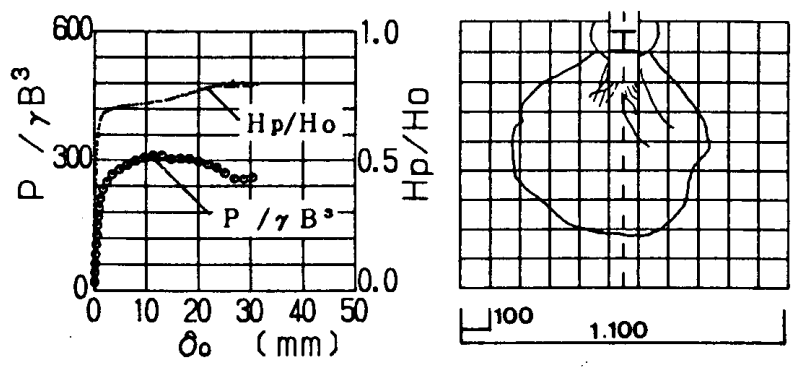

c. H形杭 $(H=24.30 \mathrm{~cm})$

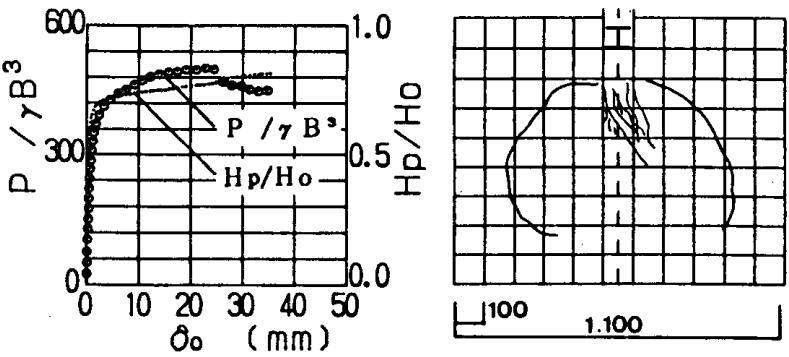

d. H形杭 $(H=29.16 \mathrm{~cm})$ 


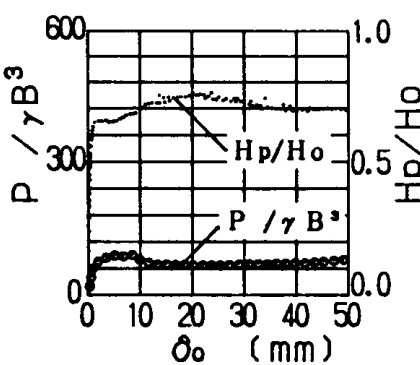

a. T形杭 $(H=14.56 \mathrm{~cm})$

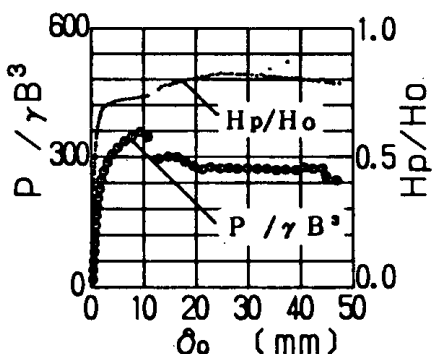

c. T形杭 $(H=24.30 \mathrm{~cm})$

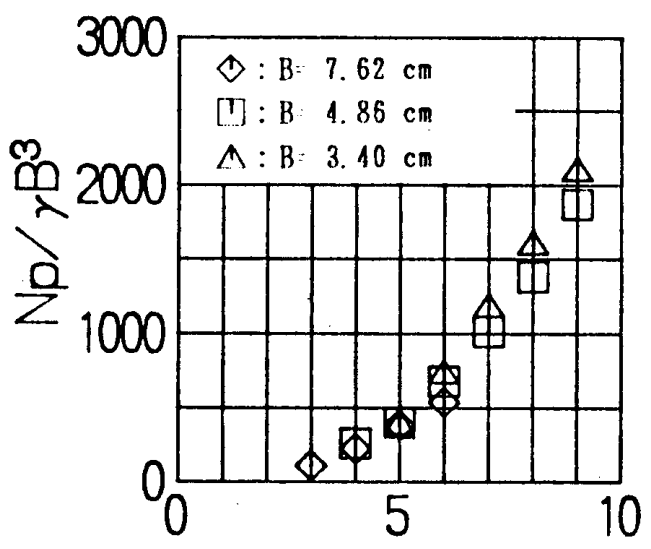

$\mathrm{Ho} / \mathrm{B}$

図-22

表一7

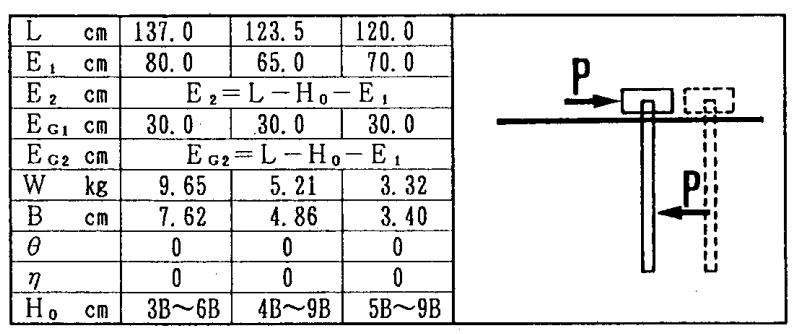

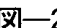

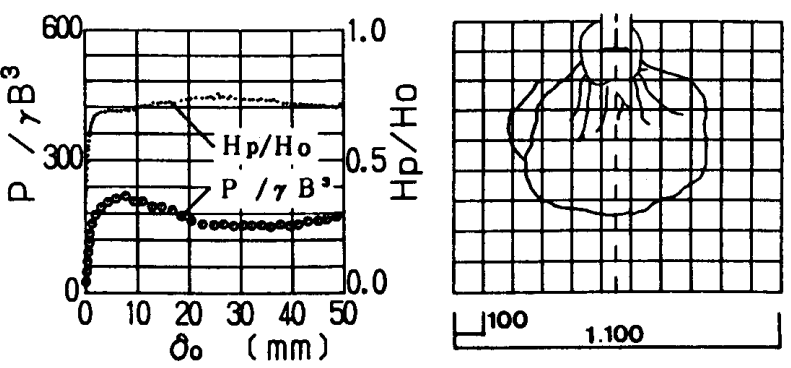

b. T形杭 $(H=19.44 \mathrm{~cm})$
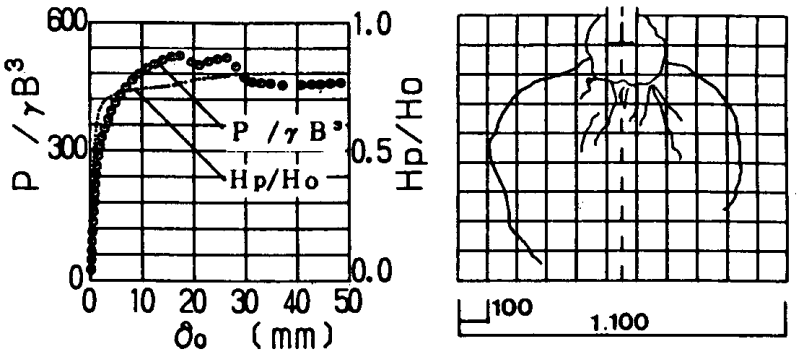

d. T形杭 $(H=29.16 \mathrm{~cm})$

T形杭

(3) 地表面に表れる地盤の崩壊形状は，いずれの杭も ほぼ円形をなし，杭断面形状による顕著な差は認められ ない（図一19－図一21）。

4.5 実験 V（水平土圧を作用させた断面寸法の異な る鉛直円形杭の受働土圧実験)

本実験は, 断面寸法が異なる 3 種類 $(B=3.40 \mathrm{~cm}$, $4.86 \mathrm{~cm}, 7.62 \mathrm{~cm})$ の鉛直円形杭に対して, 水平土圧 を作用させた受働土圧実験を行い，杭断面の寸法効果を 検討することを目的として行ったものである（表一7）。

図一 22 は $N_{\mathrm{P}} / \gamma B^{3}-H_{0} / B$ 曲線, 図一 23 は $H_{0} / B=5$, 図一 24 は $H_{0} / B=6$, 図一 25 は $H_{0} / B=7$ を同じくする 3 種類の径に対する $P / \gamma B^{3}-\delta_{0}$ 曲線を表したものであ る。

これらの結果より以下のことが考察される。

(1) 同一の根入長さ比 $\left(H_{0} / B\right)$ を有する杭では, 小 径杭の方が大径杭よりも受働土圧の無次元量が大きく なっており，寸法効果の存在を示している（図一22）。

(2) 受㗢土圧の無次元量において, 根入長さ比が小さ い方が大きいものより杭径による差がなく, 根入長さ比

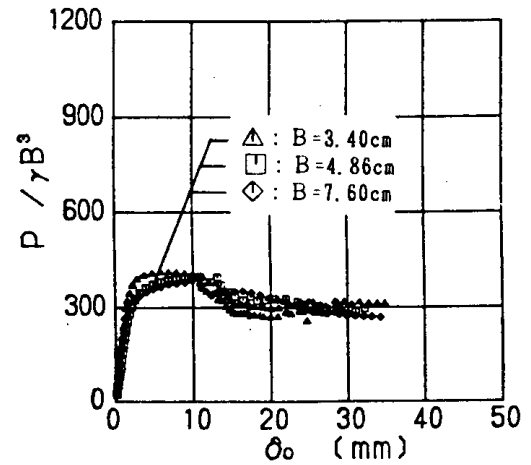

図-23 $H_{0} / B=5$

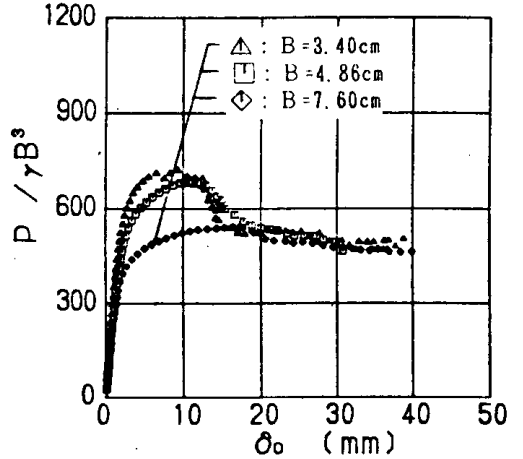

图一24 $H_{0} / B=6$

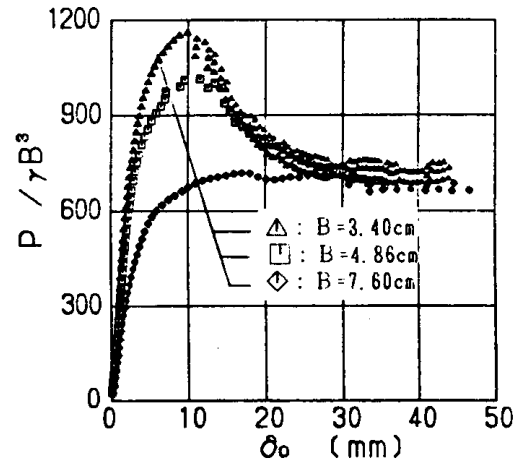

图一25 $H_{0} / B=7$ 


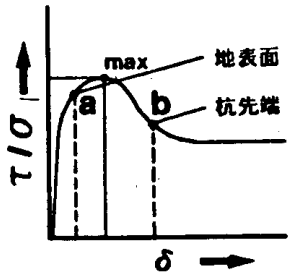

図一26

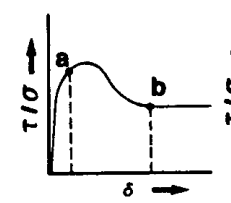

a 大径杭

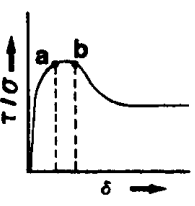

b 小径杭
図-27

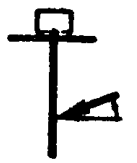

$\eta=-20^{\circ}$

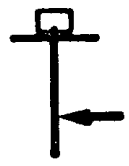

$0^{\circ}$

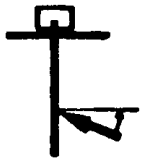

$+20^{\circ}$

図一30 実験 VI

が大きくなると断面寸法の影響(寸法効果)が大きくなっ ている（図一23一図-25）。

(3) 最大土圧以降, 土圧合力 $P$ の無次元量は一定值 に漸近する傾向にある（図一-23〜図一25）。

上記考察に関して, 地盤の崩壊が進行性破壊となる場 合, 杭先端部と地表面ではすべり量に差が生じ, 同じ相 似比をもつ杭では，杭径が大きいものほどすべり長さが 大きくなるため，杭先端と地表面のすべり量の差は大き くなることが予想される。受働土圧状態における杭先端 部と地表面のすべり量とせん断抵抗の関係は，図一26 に示すように, 最大值を挟んで, 地表面では $\mathrm{a}$ 点, 杭先 端部では b 点の関係にあり, 受働土圧はこの間の平均的 せん断抵抗によって与えられることが推測される。上記 (1)に述べた寸法効果が, 進行性破壊およびすべり量とせ
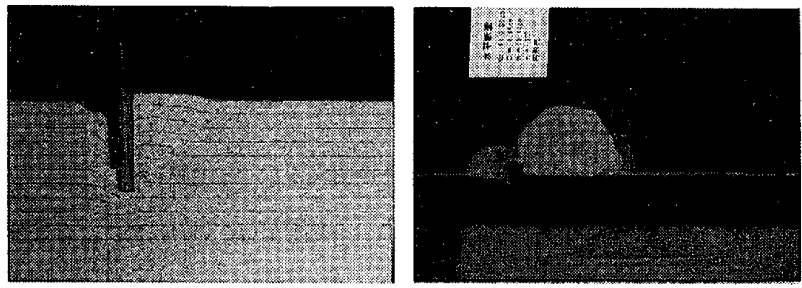

写真 $-5-\mathbf{a} \quad \eta=-20^{\circ}$

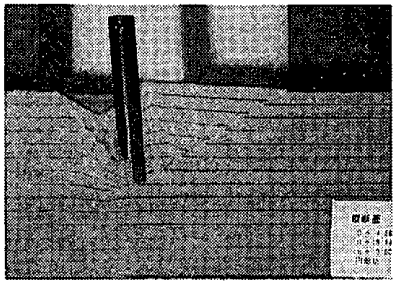

写真 -6-a $\eta=0^{\circ}$

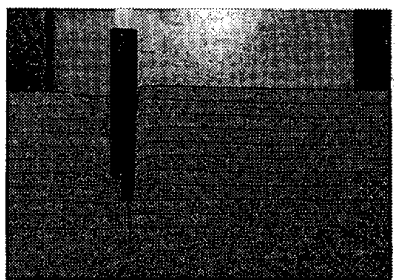

写真-7-a $\quad \eta=+20^{\circ}$

写真 $-5-\mathrm{b} \quad H=0.0 \mathrm{~mm}$

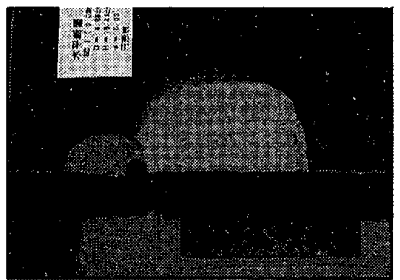

写真 $6-\mathrm{b} \quad H=0.0 \mathrm{~cm}$

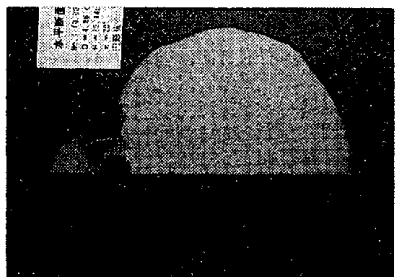

写真-7-b $\quad H=0.0 \mathrm{~cm}$

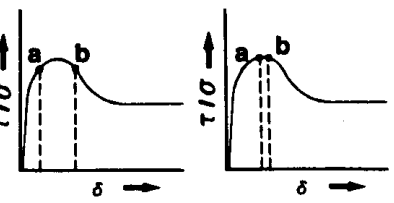

a 大径杭

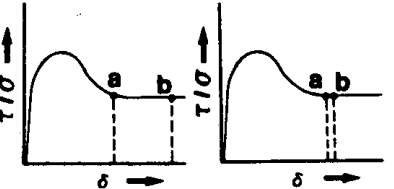

a 大径杭 b 小径杭

国-29

ん断抵抗との関係に起因するものと仮定し，すべり線に おけるせん断応力の無次元量 $\tau / \sigma(\tau$ ：せん断応力, $\sigma$ ：垂直応力）とすべり量 $\delta$ との関係が図一 26 に示した 関係にあるものと仮定すれば，次のように説明すること ができる。すなわち, 杭径が大きい場合, 杭先端部と地 表面ではすべり線の絶対長さが大きくなるため，すべり 量の差が大きく，すべり面に働く平均的せん断応力の無 次元量は小さくなる（図一27一a）。一方，杭径が小さい 場合は，すべり量の差は小さく，平均的せん断応力の無 次元量は大きくなる（図一27一b）。したがって，受働 土圧の無次元量は杭径が小さい方が大きくなる。また， 上記仮説によって，(2)および(3)が説明される。すなわち， (2)において，すべり量とせん断応力の無次元量の関係は 図一28一a，図一28一bに示す関係にあり，杭先端部と 地表面との絶対すべり量の差が小さく，せん断抵抗の平 均値（無次元量）に差がなくなり，その結果寸法効果の 影響は少なくなる。(3)においてすべり量とせん断抵抗は 図一29-a，図一29-b の関係にあり，せん断応力の無 次元量は杭径の大小共に同一值となる。したがって, 受 働土圧の無次元量は同一値となる。

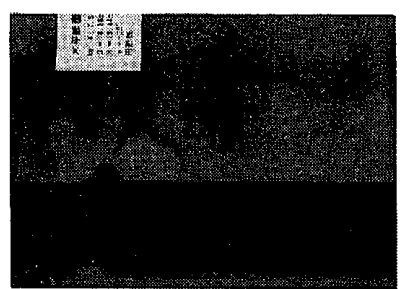

写真 $-5-\mathrm{C} \quad H=7.5 \mathrm{~cm}$

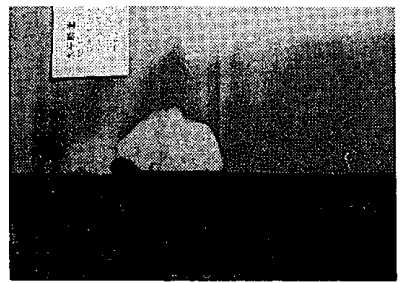

写真 $6-\mathrm{c} H=7.5 \mathrm{~cm}$

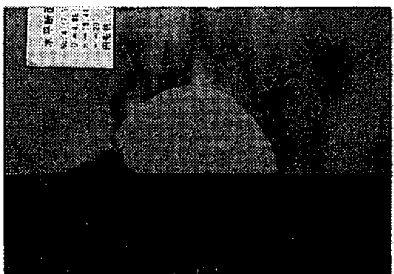

写真一7-c $H=7.5 \mathrm{~cm}$

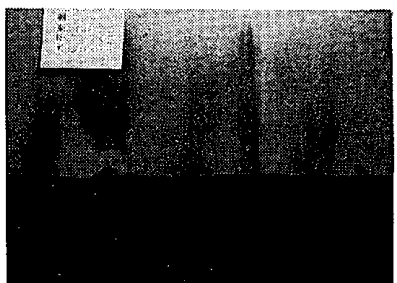

写真 -5-d $H=15.0 \mathrm{~cm}$

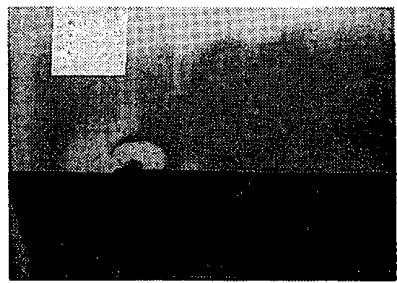

写真一6-d $H=15.0 \mathrm{~cm}$

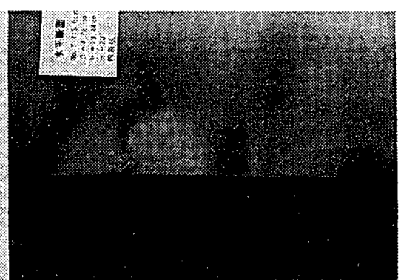

写真-7-d $H=15.0 \mathrm{~cm}$ 
以上は，水平土圧を作用させた円形鉛值杭の寸法勃果 に関する実験とそのメカニズムに関する考察である。こ れについてはさらに研究を行う必要があるが, 寸法効果 の原因として上記仮説が成立するものとすれば，杭径に 対する平均的せん断応力の評価について究明することに よって実大杭の問題に適用させることが可能ではないか と考えている。

4.6 実験 VI（水平および斜め土圧を作用させた鉛直 円形杭の地中受働崩壊形状の観察実験）

本観察実験では，まず対称縦断面でカットし，その受 働崩壊形状を写真撮影によって観察する。そして，残さ れた半分を $2.5 \mathrm{~cm}$ 間隔で設けた着色層 (3.4 参照) の 位置で平行にカットし, 各深さの水平断面の崩壊形状を 観察する。この時, 崩壊していない領域は着色層が現れ, 崩壊領域は着色していない層となり，崩壊領域の輸郭が 現れる。なお，本観察試験は径 $B=4.86 \mathrm{~cm}$ ，根入長さ $H_{0}=19.4 \mathrm{~cm}$ の円形杭に対して, 土圧の傾き $\eta=-20^{\circ}$, $0^{\circ},+20^{\circ}$ の 3 種類について行った（図一 $-30 ） 。$ 写真 5 7 は地中崩壊形状を示したものであり，a は対称繸断面， $\mathrm{b}$ は地表部の水平断面, $\mathrm{c}$ は中間部 $(H=7.5 \mathrm{~cm})$ の水 平断面, $\mathrm{d}$ は杭先端近く $(H=15 \mathrm{~cm})$ の水平断面の崩 壊形状である。

これらより以下のことが考察される。

(1) 対称縦断面に現れるすべり線はほぼ直線をなし， そのすべり線と杭との角度は，土圧の傾きが正の向きに 大きくなると増大する。

(2) 水平面に表れる地盤の崩壊形状はいずれの深さに おいてもほぼ円形をなし，その大きさは土圧の傾きが正 の向きに増大すると大きくなり，負の向きに増大すると 小さくなっている。これらの結果は，前述した実験 Iに おける地表面の崩壊形状の関係に対応している。

\section{5. 総 括}

本研究は，まだ改良の余地を残すものであるが，杭の 受働土圧の実験法および地盤の内部崩壊形状の観察法に 関して，独自の方法を考案した。また，この実験法によ り, 数多くの模型実験を行い, 短い杭の受働土圧に関し $\tau$, 以下の成果を得た。

(1) 実験 Iにおいて，鉛直杭の受働土圧の大きさは， 土圧の傾きに依存することが理解されだ。

(2) 実験 IIにおいて，水平土圧が作用する場合，受働 土圧の大きさは，杭の傾きによる影響が小さいことが理 解された。

(3) 実験而において，受働土圧の大きさは，杭が正の 傾きをもち，土圧方向が水平面に対して上向きになると 大きくなり，逆に杭が負の傾きをもち，土圧方向が下向 きになると小さくなることが理解された（図一14）。

(4) 実験 I の土圧の傾き之実験 III土土圧の傾きは, 水 平面に対して同一值であり（図一8，図一14），それぞれ
の受働土圧はほぼ同等な値を示している（図一10，図一 16)。これらと，上記(2)とを考え合わせると，杭の受働 土圧の大きさは, 水平方向に対する土圧の傾きに依存し， 杭の傾きによる影響が少ないことが理解される。

(5) 実験 I 実験 Vより,杭の受㗢土圧の合力位置は, 三角形土圧分布の合力位置よりも深くなることが観測さ れた。

（6) 実験Iにおいて，受働土圧の大きさおよび崩壊形 状は，杭の断面形状による影響が小さいことが理解され た。

(7) 実験 Vにおいて, 杭断面が大きくなるに従って, 受働土圧の無次元量が小さくなる寸法効果の存在を確認 した。また，この寸法効果は，地盤のすべり量とせん断 抵抗の大きさの関係によって説明できることが分かっ た。

（8) 実験 I 〜実験 $\mathrm{V}$ より，地表面の崩壊形状はほぼ円 形をなし，その大きさは，水平方向に対する土圧の傾き に依存し，杭の傾きによる影響は少ないことが理解され た。

(9) 実験りにおいて, 地盤の水平断面の受㗢崩壊形状 は，いずれの深さにおいても，ほぼ円形をなすことを確 認した。また，土圧の傾きが正方向に大きくなると，杭 先端から発生するすべり線角度（杭軸との角度）は増大 し，負方向に大きくなると減少することが理解された。

6. おわりに

以上のように，本研究によって砂地盤における杭の受 働土圧に関して多くの知見を得た。今後，この成果を基 に杭の受働土圧の解析法 (1984) の修正を行い, 種々の 杭の水平支持力問題に適用することを考えている。

\section{謝 辞}

本研究は東京電力株式会社の委託研究により実施した ものであり，関係者各位に深く感謝いたします。また， 本研究を卒業研究として選び，本実験に協力頂いた日本 大学理工学部海洋建築工学科本研究室卒業研究生に感謝 致します。

\section{参考文献}

1）国府田誠，栢並 昭：「杭の水平極限支持力の理論的解析 法に関する研究（斜杭および斜的荷重を含む）第 1 報杭 の受働土圧に関する解析法」日本建築学会論文報告集, 345 号, pp. 79 91, 1984

2）土質工学会：土のせん断試験法に関する基礎的研究, 1968

3）国府田誠，山下利夫，ほか：「砂地盤における杭の受働土 圧に関する実験的研究その 1 目的および実験法」日本建 築学会大会学術講演会梗概集, 1988

4）国府田誠，山下利夫，ほか：「砂地盤における杭の受㗢土 圧に関する実験的研究その 2 鉛直杭の受鮽土圧」日本建 築学会大会学術講演会梗概集, 1988

5）国府田誠，山下利夫ほほか：「砂地盤における杭の受働土 
圧に関する実験的研究その 3 斜め杭の受働土圧」日本建 築学会大会学術講演会梗概集, 1988

6）国府田誠，山下利夫ほほか：「砂地盤における杭の受働土 圧に関する実験的研究その 4 断面形状の影響」日本建築
学会大会学術講演会梗概集, 1988

7）国府田誠，山下利夫，ほか：「砂地盤における杭の受働土 圧に関する実験的研究その 5 寸法効果および結論」日本 建築学会大会学術講演会梗概集, 1988

\section{SYNOPSIS}

UDC : 624. $154: 624.131 .524 .4$

\section{EXPERIMENTAL STUDY ON THE PASSIVE EARTH PRESSURE OF A PILE IN CONSIDERING THE INCLINE OF EARTH PRESSURE AND THE INCLINE OF A PILE IN SAND}

by Dr. MAKOTO KOUDA, Prof. at Nihon Univ, and Mr. TOSIO YAMASITA, at the Tokyo Electric Co. Inc. Mr. HIDETo SATO, Graduate Student., at Nihon Univ. Dr. AKIRA ENAMI, Prof. at Nihon Univ., Members of A. I. J.

\section{OBJECTIVE}

To obtain the properties of passive earth pressure of a pile by conducting model experiments of lateral earth pressure in sand, and to develop a analytical method.

\section{CONTENTS}

We carried out model experiments of the inclined earth pressure in considering the friction between a pile and sand, and examined the effects of the shape of a pile, effects of an incline of earth pressure, effects of an incline of the pile, etc.

3. RESULTS

We confirmed the following by the model experiments :

(1) The incline of the earth pressure increases as the angle is increased under, and the decreases as the angle is increased up. This was proven by an experiment where a vertical pile was subjected to inclined earth pressure.

(2) When the lateral passive earth pressure of vertical piles have a circular section, $\mathrm{H}$ and $\mathrm{T}$ do not depend on the shape of the section.

(3) The passive earth pressure of the pile are affected largely by an incline of earth pressure rather than an incline of the pile.

(4) Horizontal sections revealing the collapsed patterns of sand are mostly circular at the surface, the middle of the pile and near the pointed end of the pile. 